Гумен Олександра Ігорівна, кандидат мистецтвознавства, доиент кафедри „Оркестрові інструменти” Дніпропетровської академії музики ім. М. Глінки

тел. (067) 590 - 59 - 43 e-mail: humenv@bigmir.net

\title{
АРФА У КАМЕРНИХ АНСАМБЛЯХ - СУЧАСНИЙ ВИМІР
}

Мета роботи - вияв особливостей тлумачення тембру арфи в українській камерній музиці останньої третини XX - початку XXI століть. Методологія дослідження грунтується на поєднанні інтонаційного та стильового методів аналізу. Використовується також структурно-аналітичний метод, на основі якого досягається відповідна логіка викладення матеріалу та формуються висновки дослідження. Вивчення теми відбувається й шляхом застосування структурно-генетичного аналізу i синтезу, як методів, що дозволяють виокремити найбільш характерні, генні елементи арфи у камерних ансамблях та зосередитись на цілісності їі сприйняття у сучасній камерній музиці. Основу практичної розробки теми складає низка емпіричних методів, а саме спостереження та узагальнення. Наукова новизна роботи полягає у тому, що в статті вперше проаналізовано камерні композиції 3 арфою у складі сучасних українських композиторів, зокрема Борислава Стронька, висвітлено питання значення камерних творів із арфою у складі в процесі становлення якісно нового етапу української виконавської культури кінця XX - початку XXI століть. Стаття розкриває унікальність тембру арфи у іiі ансамблевому поєднанні, що утворює нову своєрідність темброво-колористичних забарвлень в сучасній академічній камерно-інструментальній творчості. Висновки. Особливість тлумачення арфи у камерній музиці сучасних українських авторів характеризується відходом від тембровоколористичної та суто концертно-віртуозної інтерпретації інструменту, притаманної творам XIX - першої половини XX ст. 
Композиторська практика засвідчує значну еволюцію технічних можливостей інструменту, його потужний виражальний потенціал; у кожному конкретному випадку тембр арфи, іiі виконавські можливості здатні створити саме ту цілісну музичну картину світу, що відповідає сучасним естетико-стильовим пошукам українських композиторів.

Ключові слова: арфа, арфове виконавство, камерний ансамбль з арфою, композитор Б. Стронько.

Гумен Александра Игоревна, кандидат искусствоведения, доцент кафедры „Оркестровые инструменты” Днепропетровской академии музыки им. М. Глинки

\section{Арфа в камерных ансамблях - современное измерение}

Цель работы - выявление особенностей трактовки тембра арфы в украинской камерной музыке последней трети XX - начала XXI веков. Методология исследования основана на объединении интонационного и стилевого методов анализа. Используется также структурно-аналитический метод, на основе которого достигается определённая логика изложения материала и формируются выводы исследования. Изучение темы происходит и путём применения структурно-генетического анализа и синтеза, как методов, которые позволяют выделить наиболее характерные, генные элементы арфы в камерных ансамблях и сосредоточиться на целостности её восприятия в современной камерной музыке. Основу практической разработки темы составляет ряд эмпирических методов, а именно наблюдение и обобщение. Научная новизна работы состоит в том, что в статье впервые проанализированы камерные композиции с арфой в составе современных украинских композиторов, в частности Борислава Стронько, освещен вопрос значения камерных произведений с арфой в составе в процессе становления качественно нового этапа украинской исполнительской культуры конца XX - начала XXI веков. Статья раскрывает уникальность тембра арфы в её ансамблевом единении, что создаёт новое своеобразие темброво-колористических красок современного академического камерно-инструментального творчества. Выводы. Особенность трактовки арфы в камерной музыке современных украинских авторов характеризуется отступлением от тембровоколористической и чисто концертно-виртуозной интерпретации 
инструмента, присущей произведениям XIX - первой половины $\mathrm{XX}$ веков. Композиторская практика подтверждает значительную эволюцию технических возможностей инструмента, его мощный выразительный потенциал; в каждом конкретном случае тембр арфы, её исполнительские возможности способны создать именно ту целостную музыкальную картину мира, которая отвечает современным эстетико-стилевым поискам украинских композиторов.

Ключевые слова: арфа, арфовое исполнительство, камерный ансамбль с арфой, композитор Б. Стронько.

Humen Oleksandra, the candidate of art, the associate professor of the „Orchestral instruments" chair into the Dnipropetrovsk Academy of Music named by Glinka

\section{The harp in chamber ensembles is the modern measuring}

The purpose of this investigation is to discover the features which interpret the timbre of the harp in the Ukrainian chamber music the last third of XX - the beginning of the XXI century. The research methodology is based on the combination of intonation and style methods of analysis. The structurally analytical method is also applied by researcher, which gives foundation for accomplishment specific logic of presenting material and forming the conclusions of disquisition. Structurally genetic analysis and synthesis is employed by scholar as the way studying of subject and as methods, which allows to underscore the most characteristic, genetic elements of harp to the chamber ensembles and to concentrate on the indivisibility of its perception into the modern chamber music. The series of empirical methods consists of base for practice elaboration of theme, it is observation and generalization. The scientific novelty of the work is that, that the chamber compositions with harp in the structure of the modern Ukrainian composers such as Borislav Stronko were analyzed for the first time. Also the questions about the value of chamber works with harp in staff in the process of formation of a qualitatively new stage of the Ukrainian performance culture in the late XX - the beginning of the XXI century. The unique timbre of harp in its ensemble unity is discovered by this article, that creating the new peculiarity of timbre-coloring paints for contemporary academic chamber-instrumental creation. Conclusions. The peculiarity of the interpretation of the harp in chamber music of the modern 
Ukrainian authors is characterized by deviation from the tone-color and pure concert-virtuoso interpretation of the instrument, inherent in the works of XIX - the first half of the twentieth century. The composition practice shows a significant evolution of technical resources of the instrument, its powerful potential; in each particular case the timbre of the harp, its performance capabilities able to create the completed musical picture of the world that corresponds to the modern aesthetic and stylistic search of Ukrainian composers.

The key words: harp, the harp performance, chamber ensemble with harp, a composer B. Stronko.

Постановка проблеми. На сьогодні $\epsilon$ очевидним, що розвиток сучасного академічного камерно-ансамблевого музикування яскраво позначається різноманітністю інструментального складу його учасників. Безумовно, широкий арсенал інструментів утворює й відповідну темброво-колористичну своєрідність звучання камерного колективу. Самобутньою ознакою нової ансамблевої звучності й постає унікальність тембрової природи арфи, яка все більше позначається творчою активністю у царині академічного камерно-ансамблевого виконавства.

Але ж наголосимо, що дослідження імплементації нової тембрової колористики 3 огляду ансамблевої активізації художнього єства арфи не знаходить відповідного науководослідницького вивчення, що, безсумнівно, являє одну 3 найважливіших проблем сфери сучасного камерно-ансамблевого музикування з арфою у складі.

Актуальність дослідження визначена тим, що у другій половині XX століття кардинального оновлення жанрово-стильових засад набуває камерно-інструментальний жанр. Поширюються камерні твори, визначені авторами як симфонії, які формально, не відповідаючи ознакам жанру, концепційно, а нерідко i за масштабами, наближаються до симфонічних форм. Досить часто як один із солюючих голосів до складу ансамблю в творах такого типу включено арфу.

Огляд літератури. Відзначимо, що мистецтво гри на арфі $\epsilon$ маловивченим у сучасній науково-дослідницькій думці. Проблеми виконавсько-технологічного характеру, питання високохудожнього академічного репертуару для арфи, відповідна жанрово-стильова, 
темброво-динамічна, колористична проблематика періоду межі XX - XXI сторіч $є$ майже недослідженими у сучасному музикознавстві.

Мета статті полягає у вияві особливостей тлумачення тембру арфи в українській камерній музиці останньої третини XX початку XXI століття.

Об'сктом дослідження постає камерно-ансамблеве виконавство з арфою у складі, а предметом - ідентифікація тембру арфи у його найбільш своєрідних інтерпретаційних рисах представлених у вітчизняній камерній музиці перетину XX - XXI століть.

Виклад основного матеріалу. Результатом пошуків нових тембральних фарб та незатертої практикою виражальності стали твори, написані для арфи у комбінаціях із струнними, духовими, клавішними та ударними інструментами. Особливо поширеними $\epsilon$ дуети арфи 3 фортепіано або флейтою. Зустрічаємо чимало прикладів поєднання арфи із найрізноманітнішим інструментарієм: арфа та дзвони в Сюїті для камерного оркестру В. Степурка (1982); арфа, гітара, челеста, дзвони та вокал у „Епітафії пам’яті Рільке” Л. Грабовського (1965, друга ред. 1975); гобой, альт та арфа у „Візерунках” Л. Грабовського (1969); альтова флейта, арфа та струнний ансамбль у Камерному концерті В. Загорцева (1981); „Ноктюрн” для арфи і флейти Ж. Колодуб; „Концерт-ноктюрн” для скрипки та арфи (1973) й тріо для арфи, скрипки і віолончелі „Світ за хатою” (2009) В. Губи; „Шість Хоку” на слова японських поетів для голосу та арфи (1972), дует для флейти та арфи „Партита” (1973), Квінтет для двох скрипок, альта, віолончелі та арфи (1974) Ю. Іщенка; тріо для арфи, флейти й альта „Технемо № 3” та тріо для арфи, флейти і віолончелі „Технемо № 2” Г. Ляшенка (прем’єри виконання відбулись у 2012 та 2013 роках) тощо. Арфа у цих творах долучається до створення конкретної образності, певної атмосфери або підсилює емоційно психологічний аспект авторського задуму.

Аналізуючи творчість для арфи українських композиторів Г. Ляшенка, Ю. Іщенка та Б. Стронька, В. Загорцева - попри яскраву стильову індивідуальність їх авторів, виявляємо загальну генералізуючу тенденцію тлумачення арфи в сучасній музиці. Ії суть визначається відходом від темброво-колористичної та суто концертно-віртуозної інтерпретації інструмента, притаманної 
творам XIX - першої половини XX ст. Інтонаційно-стильовий зміст проаналізованих творів засвідчує значну еволюцію технічних можливостей інструмента, його потужний виражальний потенціал. Композиторська практика у кожному конкретному випадку доводить, що тембр арфи, ऑiі виконавські можливості здатні створити саме ту цілісну музичну картину світу, що відповідає сучасним естетико-стильовим пошукам українських композиторів.

В. Загорцев досить широко використовує у власних композиціях тембр арфи. До творів, у яких залучено арфу, належать „Містерія” для фортепіано 3 оркестром (1965), „Градації” для камерного оркестру (1966) (виконання цього твору в Нью-Йорку в 1980 році мало успіх і зробило ім'я Володимира Загорцева відомим в усьому світі), „Ігри” для камерного оркестру (1968), Симфонія „Тривоги” для камерного оркестру (1988) [1].

Однак у творах композитора звучність арфи може використовуватись не лише як складова тембрової палітри, але й набуває домінуючої функції у створенні образного задуму. Це Фантазія для віолончелі, арфи та ударних (1971), а також Камерний концерт № 1 для альтової флейти, арфи і струнних (1981) (першою та єдиною на сьогодні виконавицею цих творів в Україні $\epsilon$ арфістка, солістка Національного заслуженого академічного симфонічного оркестру України Наталія Ізмайлова).

Фантазія для віолончелі, арфи та ударних В. Загорцева $\epsilon$ зразком естетики і техніки українського музичного авангарду другої половини ХX ст. Титульні ознаки „новаторського” тут проступають на усіх художніх рівнях. Насамперед, це домінування „інструментальної” ідеї, що реалізується у творі різнобічно та багаторівнево. 3 позиції жанрових параметрів твір презентує „чисту” інструментальну, не програмну музику, камерність якої є їі внутрішньо-іманентною ознакою. Типовою для естетики авангарду є також не канонічність виконавського складу (віолончель, арфа й ударні) та особливості музичного тематизму. В традиції авангардних шукань у Фантазії $\epsilon$ відсутня музична тема в класичному розумінні. Головним героєм Фантазії стає звук як такий. Саме звучання окремої інтонації формує образну категорію та музичну драматургію цілісності. Домінування „звукової концепціï” у творі підкреслено постановчими прийомами, зафіксованими композитором у численних ремарках. Важливими 
для втілення цієї концепції твору є електронне підсилення звуку партій віолончелі та арфи системою окремих динаміків. Доробок митця засвідчує, що арфа цікавить його не тільки своїми удосконаленими технічними можливостями, але й трансформується і як важливе джерело нової виражальності в різноманітних жанрах.

Ю. Іщенко поєднує арфу і флейту в „Партиті”. Час створення восьми „Маленьких партит” охоплює 30 років: перша написана у 1973, остання - у 2003 р. Композитор не мав наміру оформлення партит в єдиний цикл - багато 3 них мають власну історію виникнення, кожна розрахована на свій склад виконавців, деякі, через ряд обставин, були перекладені для інших інструментів [2].

Першу партиту, написану для флейти й арфи, композитор згодом переклав для скрипки та фортепіано, а в концертному виконанні іiі можна почути навіть із клавесином. Цікава за задумом, але складна для виконавця, може саме технічна складність арфової партії і спричинила до перекладення твору для фортепіано, а в концертному виконанні ії можна почути навіть з клавесином.

Мотивом створення першої партити слугувало замовлення (скоріше прохання) на сюїту для флейти 3 арфою. Сюїти не сталось: трансформація ритму у 4-ій частині призвела до появи у фіналі не жиги, а сициліани. Так цей цикл перетворився на партиту. „Жарт” Баха, що став основою Алеманди, з'явився 3 подання Іщенка подвоєним: одночасне використання теми у різних тональностях (партія флейти 3 двома дієзами, а арфи - 3 шістьма бемолями, а в другій половині навпаки) надало терпкості звучанню, підняло „градус" твору.

У більшості „Маленьких партит” Ю. Іщенка авторський принцип „сполучення несумісного” знаходить втілення в різноманітних прийомах розвитку тематизму, поліфонічних засобів, ланцюжковій передачі матеріалу в ансамблях, будові гармонічних та фактурних пластів, ритмічній вишуканості, оригінальності форми тощо, що народжує в підсвідомості певні сценічні образи (персонажі комедіï dell arte, жанрові амплуа, різні національні типажі й ін.).

Особливе місце в українській арфовій музиці займає створений Ю. Іщенко у 1974 р. Квінтет для двох скрипок, альта, віолончелі та арфи. Фактично це один 3 перших творів у вітчизняній музиці ХX ст., в якому арфа тлумачиться не тільки і не 
стільки $з$ погляду притаманної ій колористики звучання, а виступає чинником тематичної та композиційно-драматургічної цілісності твору, в якому саме концертний індивідуалізований тембр визначає весь основний тематизм композиції.

Квінтет відповідає класичним параметрам жанру iз традиційним тлумаченням функцій кожної частини чотиричастинного інструментального циклу. Так, перша частина твору (Allegro moderato) виконує роль експозиції загальної інтонаційної концепції твору; друга частина (Vivace giocoso) легке, радісне скерцо, контрастно співставлене 3 третьою драматичним монологом (Adagio epico) із вкрапленням ознак епічної стилістики. Врешті, четверта частина (Allegro geroico) традиційно швидкий енергійний фінал-узагальнення.

Попри наявність виразно окресленої класицистичної моделі жанру, Квінтет є яскраво національним за концепцією i виражальністю, зокрема, інтонаційною природою тематизму. Епічну спрямованість його образної палітри визначають різноманітні інтонаційні комплекси, серед яких: билинна декламація, веснянковий хоровод, лірична пісенність, думовий монолог, ритуальна танцювальність тощо. Монументальність задуму, драматургічна насиченість зближують Квінтет Ю. Іщенка із симфонічними жанрами, ознаки яких талановито втілені композитором за допомогою мінімальних засобів інструментального ансамблю.

До жанру камерного ансамблю із арфою у складі звертається також молодий київський композитор Борислав Стронько, творча біографія якого розпочалась в останньому десятилітті минулого століття (творчий доробок Б. Стронька представлений композиціями різних жанрів: музично-театральним (опера „Фауст”), симфонічним (Перша та Друга симфонії, Концерт для скрипки 3 оркестром, Варіації на тему В.А. Моцарта), вокальнохоровим (,Silentium” для змішаного хору, Псалом № 42, вокальний цикл на слова О. Мандельштама), камерно-інструментальними творами).

Однак, попри відносно нетривалий час творчості, композитор впевнено увійшов до вітчизняного музичного процесу і на сьогодні, поряд 3 іншими авторами, визначає обличчя сучасної української музики. 
Найбільш значним за обсягом $є$ камерно-інструментальний доробок композитора, що на сьогодні представлений фортепіанними сонатами, сольними п'єсами для різних інструментів, зокрема для арфи, а також різноманітними камерними ансамблями, переважно нетрадиційного складу: фортепіанне тріо (флейта, фагот, фортепіано), квартет „Повернення на Ітаку" (кларнет, бас-кларнет, тенор-саксофон, фагот).

Серед камерних ансамблів - твори 3 арфою. Борислав Стронько $з$ особливим пієтетом ставиться до цього інструмента. Можливо саме тому арфові твори композитора щоразу демонструють високий художній і виконавський потенціал арфи.

Арфу композитор залучає вже до своїх ранніх творів: тріо „Трава забуття” для арфи, челести та клавесину (1994); сольна п’єса для арфи-соло „Занурення” (1995). У подальшій творчості Б. Стронька арфа звучить переважно в ансамблевому поєднанні 3 іншими інструментами, струнним квартетом або струнним оркестром: Пассакалія „Плач Ізраїлю” для кларнета, арфи, скрипки, віолончелі та струнного оркестру (2001); програмні твори „Еос” для квінтету (струнний квартет 3 арфою, 2005); тріо-сюїта „Дивні казки" (ксилофон, арфа і віолончель, 2009).

У камерно-ансамблевій творчості композитора арфа виконує найрізноманітніші функції. Більшість цих творів є програмними і їхні задуми навіяні враженнями від літературного або історичного матеріалу, до того ж пов'язаним із давньою грецькою міфологією або біблійними сюжетами. Арфу в них композитор використовує і як колористичну барву для відтворенні образів-картин, і як знак певної епохи. Нерідко саме арфа покликана відтворити певні асоціації із звучністю стародавніх струнно-щипкових інструментів (гуслів, ліри, кіфари тощо) 3 метою посилення автентичності образів давнини. Так, у лірико-драматичному творі „Плач Ізраїлю” партія арфи, хоча й достатньо інертна в загальному розвитку твору, $\epsilon$ вельми важливою в драматургії, у розкритті його біблійної образності. Її звучність сприймається як знак, що переносить уяву до трагічної історії давньої Іудеї.

У розгорнутій в часі композиції „Плач Ізраїлю” композитор використовує неокласичну форму варіацій на basso ostinato i3 притаманним цьому жанровому різновиду драматургічним прийомом поступового нарощування фактури засобами 
нашарування інструментальних партій. Основу драматичного образу становить моно-тема, ядром якої $є$ піднесена до масштабів вселенської скорботи інтонація плачу. Східну архаїку цієї теми визначає насамперед iii ладове забарвлення - мажор із низькими 2 та 6 ступенями. Ламентозне звучання твору підсилює полімелодизм фактури. Фактично у кожній партії поряд із основним тематизмом повторюється інтонація плачу із головної моно-теми.

Великого значення композитор надає тембральній палітрі твору. Щоб максимально драматизувати образність, він зупиняє увагу на інструментах, звучання яких наближене до людського голосу і традиційно вживається для втілення глибоко особистісних почуттів - звідси й певна інертність в ансамблі партії арфи.

Зміст квінтету „Еос” (для арфи і струнного квартету) навіяний гомерівською „Іліадою”, що засвідчують не лише програмна назва, а й авторський епіграф у рукописі твору („Вышла из мрака младая, с перстами пурпурными Эос") (Еос, або Аврора - давньогрецька богиня вранішньої зорі). Імпресіоністично витончена пейзажкартина чарівної природи втілена композитором внутрішньо динамічно. У тричастинній формі із розгорнутою репризою експоновані в першій частині лагідні образи спокою, краси, світла (до ц. 4) змінює розробковий характер середнього розділу, де семантика втілює рух, неспокій, хвилювання. Так, початкова секундова поспівка - „інтонація зітхання” - в експозиційному викладі теми в серединному розділі переінтоновується і в новому ритмічному оформленні набирає ознак баркарольного жанру, що асоціюється із картиною хвилювання моря. Зміни образності та інтонаційно-ритмічне перевтілення вихідного тематизму розпочинаються саме у партії арфи. Хоча в подальшому розвитку арфа використовується переважно як колористична складова музичної фактури.

Інтерес автора до давньогрецької міфології спостерігаємо також i в його наступному камерно-інструментальному програмному тріо „Трава забуття” для арфи, челести та клавесину, створеного, як і квінтет „Еос” та квартет „Повернення на Ітаку”, за мотивами гомерівського епосу „Іліада” та „Одісея”.

Музичний космос тріо вибудувано на основі гармонійного співіснування двох протилежних, але не конфліктних, а взаємодоповнюючих один одного світів. Один із них - образ 
спокою, рівноваги, краси, втілення якого і доручено саме арфі. У широких, розлогих арпеджіо зринають уривки витонченої мелодії; вона не обривається, не зникає, просто звучить нібито у різних вимірах. Картину „прекрасного” доповнює ніжний, витончений тембр челести.

Паралельно „ідеальному” в тріо існує також інший світ, зокрема акт, втілений в образи, сповнені руху, однак не енергійнодинамічного, а скоріше ритмічно-механічного. Такої якості їм надають металевий тембр клавесина i послідовне звучання загальних фігураційних формул руху, як основи музичного тематизму.

Як зазначалось, протилежні за змістом образи не конфліктують, а доповнюють один одного. Лише на рівних етапах становлення музичної форми кожен із образів виходить на перший план, однак не поступово витісняючи, а ніби „відключаючи” власну протилежність. Так, образ механічного домінує у середньому розділі форми (ц. 3-7). Показово, що тембр арфи як носія „прекрасного” у цій частині загальної форми взагалі „знято”, звучать лише челеста і клавесин, а згодом лише клавесин. В образно-інтонаційному плані відбувається наростання зовнішньої моторики: засобами обмеженої алеаторики композитор створює враження невпинної пульсації фігураційних хвиль.

Відродження образу краси (динамізована реприза від ц. 7) відбувається за принципом „включення”: початкова тема 3'являється у своєму основному тембровому оформленні - у арфи і челести. При цьому клавесинові фігурації не зникають, вони творять витончене тло для звучання солюючих інструментів. У коді твору (ц. 9) алеаторичні фігурації поширюються у всіх партіяхтембрах композиції, що підтверджує ідею гармонійного співіснування протилежностей.

У тріо композитор вирішує також питання синтезу тембрів. За його словами, цікавим з технічної сторони було поєднання „,тихих і нединамічних" інструментів - челести і клавесина $з$ арфою, з метою виявити іiі значний, по-вокальному співучий та динамічний потенціал. Одним із останніх на сьогодні творів Б. Стронька, в якому задіяна арфа, є сюїта „Дивні казки” (за останньою редакцією автора „Чудернацькі казки”, прем’єра відбулася 12 жовтня 2011 року на ювілейному концерті народної артистки України Наталії 
Ізмайлової в концертному залі спілки композиторів України у виконанні: О. Гумен (арфа), О. Заяць (віолончель), С. Ульянов (ксилофон)) для ксилофона, арфи і віолончелі, що була створена за мотивами казки про загублене стародавне місто (з циклу східних казок „Тисяча та одна ніч”). Твір складається 3 п'яти частин, кожна 3 яких має програмну назву, що по суті і визначає їхню жанровоілюстративну спрямованість.

У циклі „Казок” тембр арфи відіграє переважно колористичну функцію - посилює фантастичні ефекти. Особливо це очевидно у першій частині - „Казка про згасле вогнище”, де партія арфи разом iз ксилофоном створює колористичне тло, на якому звучить експресивна і напружена мелодія віолончелі. Однак, починаючи 3 другої частини циклу функції арфи зростають. Надалі іiі тембр уводиться до відтворення основних образів кожної частини. У другій частині - „Казка про світлий дощ” - це відтворення крапель дощу; у третій - „Казка про вітер, що танцює” - звуконаслідування поривів вітру (висхідні та низхідні пасажі). Особливо вирізняється частина „Казка про годинник, що засинає”, де автор доручає арфі солюючу партію - розмірена із дублюванням в октаву мелодія у поєднанні з остінатними фігурами ксилофона і педальними тонами віолончелі створює механічний, застиглий образ часу. Фінал циклу - „Казка про глузливого птаха” вирівнює значення звучності всіх інструментів, створюючи цілісний образ радості.

Арфові твори композитора Борислава Стронька демонструють високий художній і виконавський потенціал інструмента. Звучність арфи у них відображає насамперед тонус процесів, їх енергетику, тобто „як” відбувається, а не „що”. Програмна назва, словесний текст, відеоряд звичайно конкретизують їх зміст, однак присутність цих підказок не $є$ обов'язковою. Вербальні моменти лише полегшують сприйняття творів, пов'язуючи їх зміст, образність із життєвим досвідом, усталеним тезаурусом слухача.

Висновки. На підставі проведеного аналізу камерних творів можна констатувати, що тлумачення арфи у камерній музиці сучасних українських авторів характеризується потужним виражальним і виконавським потенціалом; у кожному конкретному випадку тембр арфи, іiі виконавські можливості здатні створити саме ту цілісну музичну картину світу, що відповідає сучасним естетико-стильовим пошукам відомих українських композиторів. 
Перспективи дослідження вбачаються у зверненні наукового погляду на більш ширший арсенал засобів художньої виразності арфи, виявленні його своєрідності як у сольному, так і ансамблевому академічному професійному виконавстві.

\section{Список використаних джерел і література:}

1. Гумен О. Арфа в творчості Володимира Загорцева // Вісник Прикарпатського університету. Серія: Мистецтвознавство: зб. наук. ст. ІваноФранківськ, 2011. Вип. XXI-XXII. С. 354-357.

2. Гумен О.Ю.Іщенко. Квінтет для арфи, двох скрипок, альта й віолончелі // Камерно-інструментальний ансамбль: історія, теорія, практика: зб. наук. ст. Львів: Споло, 2010. Вип. 24. С. 263-271.

3. Олійник О. Історія становлення і розвитку камерного ансамблю з арфою у складі: навчальний посібник. Вінниця: Нова книга, 2005. 200 с.

4. Польская И. Камерный ансамбль: история, теория, эстетика: монографія. Харьков: ХГАК, 2001. 395 с.

5. Шамеева Н. История развития отечественной музыки для арфы (XX век). Москва, 1994. 146 с.

\section{References:}

1. Humen, O. (2011). Harp in the works of Volodymyr Zahortsev. IvanoFrankivsk: Prykarpatskyi universytet [in Ukrainian].

2. Humen, O. (2010). Y. Ishchenko. Quintet for harp, two violins, viola and cello. Kamerno-instrumentalnyi ansambl: istoriia, teoriia, praktyka, 24, 263-271 [in Ukrainian].

3. Oliinyk, O. (2005). The history of the formation and development of the chamber ensemble with the harp in the composition. Vinnytsia: Nova knyha [in Ukrainian].

4. Pol'skaja, I. (2001). Chamber ensemble: history, theory, aesthetics. Har'kov: HGAK [in Russian].

5. Shameeva, N. (1994). The history of the development of Russian music for the harp (the twentieth century). Moskva [in Russian]. 